\title{
In Vitro Bioactivity of Methanolic Extracts from Amphipterygium adstringens (Schltdl.) Schiede ex Standl., Chenopodium ambrosioides L., Cirsium mexicanum DC., Eryngium carlinae F. Delaroche, and Pithecellobium dulce (Roxb.) Benth. Used in Traditional Medicine in Mexico
}

\author{
Peter Knauth (iD, ${ }^{1}$ Gustavo J. Acevedo-Hernández, ${ }^{2}$ M. Eduardo Cano, ${ }^{3}$ \\ Melesio Gutiérrez-Lomelí, ${ }^{4}$ and Zaira López $\mathbb{D}^{1}$ \\ ${ }^{1}$ Cell Biology Laboratory, Centro Universitario de la Ciénega, Universidad de Guadalajara, Av. Universidad 1115, \\ 47810 Ocotlán, JAL, Mexico \\ ${ }^{2}$ Laboratorio de Biología Molecular Vegetal, Centro Universitario de la Ciénega, Universidad de Guadalajara, \\ Av. Universidad 1115, 47810 Ocotlán, JAL, Mexico \\ ${ }^{3}$ Laboratorio de Biofísica, Centro Universitario de la Ciénega, Universidad de Guadalajara, Av. Universidad 1115, \\ 47810 Ocotlán, JAL, Mexico \\ ${ }^{4}$ Laboratorio de Alimentos, Centro Universitario de la Ciénega, Universidad de Guadalajara, Av. Universidad 1115, \\ 47810 Ocotlán, JAL, Mexico
}

Correspondence should be addressed to Zaira López; zlopez@gmx.net

Received 29 November 2017; Accepted 29 January 2018; Published 28 February 2018

Academic Editor: Gloria Brusotti

Copyright (C) 2018 Peter Knauth et al. This is an open access article distributed under the Creative Commons Attribution License, which permits unrestricted use, distribution, and reproduction in any medium, provided the original work is properly cited.

\begin{abstract}
Seven out of eight methanolic extracts from five plants native to Mexico were inactive against ten bacterial strains of clinical interest. The fruit extract of Chenopodium ambrosioides inhibited the bacteria Enterococcus faecalis ( $\mathrm{MIC}=4375 \mu \mathrm{g} / \mathrm{ml}$ ), Escherichia coli $(\mathrm{MIC}=1094 \mu \mathrm{g} / \mathrm{ml})$, and Salmonella typhimurium $(\mathrm{MIC}=137 \mu \mathrm{g} / \mathrm{ml})$. The fruit extract of C. ambrosioides was with $\mathrm{CC}_{50}=45 \mu \mathrm{g} / \mathrm{ml}$ most cytotoxic against the cell-line Caco-2, followed by the leaf extract from Pithecellobium dulce $\left(\mathrm{CC}_{50}=126 \mu \mathrm{g} / \mathrm{ml}\right)$; interestingly, leaves of $C$. ambrosioides $\left(\mathrm{CC}_{50}=563 \mu \mathrm{g} / \mathrm{ml}\right)$ and bark of $P$. dulce $\left(\mathrm{CC}_{50}=347 \mu \mathrm{g} / \mathrm{ml}\right)$ extracts were much less cytotoxic. We describe for the first time the cytotoxic effect from extracts of the aerial parts and the flowers of Cirsium mexicanum $\left(\mathrm{CC}_{50}=323 \mu \mathrm{g} / \mathrm{ml}\right.$ and $\mathrm{CC}_{50}=250 \mu \mathrm{g} / \mathrm{ml}$, resp.). Phytochemical analysis demonstrated for both extracts high tannin and saponin and low flavonoid content, while terpenoids were found in the flowers. For the first time we report a cytotoxicological study on an extract of Eryngium carlinae $\left(\mathrm{CC}_{50}=356 \mu \mathrm{g} / \mathrm{ml}\right)$ and likewise the bark extract from Amphipterygium adstringens $\left(\mathrm{CC}_{50}=342 \mu \mathrm{g} / \mathrm{ml}\right)$. In conclusion the fruit extract of C. ambrosioides is a potential candidate for further biological studies.
\end{abstract}

\section{Introduction}

Plants are well known as a rich source of bioactive compounds with a wide range of pharmaceutical applications, for instance, neuro- or psychoactive compounds (e.g., atropine, caffeine, cocaine, and morphine), substances with antiinflammatory (e.g., acetylsalicylate) or cardiovascular effects (e.g., digoxin), or anticancer activity (e.g., taxol, vinblastine). Hence, over the last few decades raw extracts from medicinal plants have been studied in order to discover pure compounds that show any of the aforementioned biological activities.

Most of the antibiotics used in clinical and veterinary medicine are from microbial origin (bacteria, fungi) and only a few of them are synthetic. However, since the end of the "Golden Age of Antibiotic Discovery" in the 80s of the last century only a small number of new antibiotics have emerged, while on the other hand more and more antibiotics have lost 
TABLE 1: Fractions of the plants employed and concentration of the methanolic extracts. Previously reported biological activity of plant extract and their reference.

\begin{tabular}{|c|c|c|c|c|}
\hline $\begin{array}{l}\text { Plant sample } \\
\text { Voucher }\end{array}$ & \multicolumn{2}{|c|}{ Plant fraction } & Action & Reference \\
\hline \multirow{3}{*}{$\begin{array}{l}\text { Amphipterygium adstringens } \\
\text { (cuachalalate) } \\
\text { CBL201701 }\end{array}$} & \multirow{3}{*}{$\begin{array}{c}\text { Bark } \\
\text { CBM } \\
80 \mathrm{mg} / \mathrm{ml}\end{array}$} & & Antibacterial & {$[10,24-26]$} \\
\hline & & & Cytotoxic & {$[24,27]$} \\
\hline & & & Proliferation & [2] \\
\hline \multirow{5}{*}{$\begin{array}{l}\text { Chenopodium ambrosioides } \\
\text { (epazote) } \\
\text { CBL201702 }\end{array}$} & \multirow{5}{*}{$\begin{array}{c}\text { Leaf } \\
\text { ELM } \\
20 \mathrm{mg} / \mathrm{ml}\end{array}$} & \multirow{5}{*}{$\begin{array}{c}\text { Fruit } \\
\text { ESM } \\
20 \mathrm{mg} / \mathrm{ml}\end{array}$} & Antiprotozoal & {$[25,28-30]$} \\
\hline & & & Antifungal & [31] \\
\hline & & & Antibacterial & {$[32]$} \\
\hline & & & Cytotoxic & {$[33]$} \\
\hline & & & Not cytotoxic & {$[9]$} \\
\hline \multirow{3}{*}{$\begin{array}{l}\text { Cirsium mexicanum } \\
\quad \text { (cardosanto) } \\
\text { CBL201703 }\end{array}$} & \multirow{3}{*}{$\begin{array}{l}\text { Flower } \\
\text { CsFM } \\
48 \mathrm{mg} / \mathrm{ml}\end{array}$} & \multirow{3}{*}{$\begin{array}{l}\text { Aerial parts } \\
\text { CsM } \\
40 \mathrm{mg} / \mathrm{ml}\end{array}$} & Anticancer & [14] \\
\hline & & & Antidiabetic & {$[14]$} \\
\hline & & & & \\
\hline \multirow{2}{*}{$\begin{array}{l}\text { Eryngium carlinae } \\
\text { (hierba del sapo) } \\
\text { CBL201704 }\end{array}$} & \multirow{2}{*}{\multicolumn{2}{|c|}{$\begin{array}{l}\text { Aerial parts } \\
\text { HsM } \\
50 \mathrm{mg} / \mathrm{ml}\end{array}$}} & Antidiabetic & {$[30]$} \\
\hline & & & & \\
\hline \multirow{3}{*}{$\begin{array}{l}\text { Pithecellobium dulce } \\
\text { (guamúchil) } \\
\text { CBL201705 }\end{array}$} & \multirow{3}{*}{$\begin{array}{c}\text { Bark } \\
\text { GBM } \\
20 \mathrm{mg} / \mathrm{ml}\end{array}$} & \multirow{3}{*}{$\begin{array}{c}\text { Leaf } \\
\text { GLM } \\
20 \mathrm{mg} / \mathrm{ml}\end{array}$} & Antibacterial & {$[34]$} \\
\hline & & & Cytotoxic & {$[1]$} \\
\hline & & & Not cytotoxic & {$[1]$} \\
\hline
\end{tabular}

activity due to the rise of acquired resistance against them [1]. In 2005, the World Health Organization (WHO) developed a list of Critically Important Antimicrobials (CIA) for human medicine and published a global action plan to address this problem [2]. Therefore, now other niches (e.g., marine environment) and sources (e.g., animals or plants) are being investigated to discover new classes of antibiotics [3]. Mexico possesses a very high plant biodiversity with about 26,000 species already identified [4], and an estimated 4,500 plants are used for medicinal purposes [5]; but in vitro antibacterial properties have been reported for only 343 plant species [6]. Although many phytochemicals (e.g., eugenol, menthol, thymol, and linalool) or plant peptides with antimicrobial activity are known, those molecules are normally not used as antibiotics. Moreover, among those medicinal plants from Mexico, only 300 of them have documented use in anticancer treatment: 181 are supported by scientific evidence and 119 have been used empirically [7].

Amphipterygium adstringens (Schltdl.) Schiede ex Standl., commonly known in Mexico as cuachalalate, is widely used as a medicinal plant, especially to treat ulcers, cancer, gastritis, and other gastrointestinal disorders as well as promote wound healing [8]. Extracts from the bark of this plant have antibacterial activity, which is attributed to a mixture of anacardic acids (Table 1). At a concentration of $10-40 \mu \mathrm{M}$ those anacardic acids were cytotoxic to several cell lines, while other authors reported proliferative effects (Table 1). Moreover, extracts containing masticadienonic acid and its $3 \alpha$-hydroxy-derivative exhibited in rats antiulcer activity [9] and anti-inflammatory effects [10].

Chenopodium ambrosioides L., also known as "wormseed," "Jesuit's tea," or "epazote," has been empirically used in Mexico as an infusion for its antiparasitic activity and other positive effects on the gastrointestinal tract [11]: among its components, especially ascaridole and hydroperoxide derivates from monoterpenes with two double bonds exhibit antiprotozoal activity (Table 1). Moreover, its essential oils have antifungal activity; and methanol or petroleum ether extracts of the bark or flowers have antibacterial effects (Table 1). There are, however, contradictory reports on cytotoxic effects of its extracts (Table 1). Additionally, moderate antioxidant and anti-inflammatory properties could be attributed to the chenopodiumamines $\mathrm{A}$ to $\mathrm{C}$ isolated from ethanolic extracts [12]. Using an animal model, ethanolic extracts of leaves or stems exhibited anti-inflammatory, antinociceptive, and healing effects, which validate its potential therapeutical use [13].

Cirsium mexicanum DC., known as "Mexican thistle" or "cardosanto," is empirically employed by the Mexican population to treat cancer or diabetes [14], but there is no scientific contribution about the biological activity of this plant.

Eryngium carlinae F. Delaroche, known in Mexico as "hierba del sapo," is often used in traditional medicine to treat diabetes. Although an ethanolic extract of the whole plant of E. carlinae did not lower blood glucose levels in diabetic rats, a significant decrease of creatinine, urate, total cholesterol, and triglycerides could be demonstrated, which may lower the risk of renal and cardiovascular complications caused by diabetes mellitus [15]. Additionally, a methanolic extract from E. carlinae inhibits growth of Helicobacter pylori [16].

Finally, Pithecellobium dulce (Roxb.) Benth. is autochthonous to Mexico and Central America, where it is known as "guamúchil" or "huamúchil," but nowadays it can also be 
found in Southeast Asia and India, where it is known as "Madras thorn." In Mexico, the plant is traditionally prepared as aqueous infusions or ethanolic extracts from different parts of the tree: from leaves to alleviate pain and convulsions and combined with salt to cure indigestion and from bark for treatment of dysentery or fever [17]. In rats, an ethanolic seed extract has protective effects against ulceration [18] and antidiabetic activity [19], while an aqueous leaf extract shows antihyperlipidemic activity [20]. A hydroethanolic extract of the bark exhibited antimicrobial activity (Table 1). Recent cytotoxicological studies revealed cytotoxic effects of a methanolic leaf extract on the prostate cancer cell line $\mathrm{CaP}$, while no effect on the breast cancer cell line MCF-7 was observed [21].

When plants are selected on the basis of their use in traditional medicine, the first extraction step to obtain a raw extract should mimic the extraction process as described by the traditional healer [22]. In an initial screening for biological activity, the concentration ranges usually from 10 to $10,000 \mu \mathrm{g} / \mathrm{ml}$, but only raw extracts with a half maximal effective concentration $\mathrm{EC}_{50} \leq 100 \mu \mathrm{g} / \mathrm{ml}$ are considered active [23] and subjected to further analysis.

Of the five plant species included in the present study, two have not been extensively studied scientifically and for the remaining three plants the published literature shows contradictory results concerning their cytotoxicity. Therefore, we considered these five plants, which are all endemic to Mexico, as good candidates for assessment of their in vitro cytotoxicity using the human epithelial colorectal adenocarcinoma cell line Caco-2, a standard model to discover novel anticancer agents in colon cancer. Additionally, their antimicrobial activity, useful to discover novel agents to prevent and treat nosocomial infections, was evaluated.

\section{Methodology}

2.1. Plant Material and Extraction. Dried bark of A. adstringens was bought at a local market in Ocotlán (Jalisco, Mexico), while the samples of C. ambrosioides, C. mexicanum, E. carlinae, and P. dulce were collected in "La Ciénega" region (Jalisco, Mexico) between June and July. All fresh material was delivered to the laboratory and dried at room temperature (RT) by ventilation for $10 \mathrm{~d}$. Afterwards the collected material was separated according to plant parts (Table 1). Each part was ground (electrical grinder) and passed through a 30 mesh sieve to get a fine powder. Then $10 \mathrm{~g}$ of plant powder from each sample was macerated with $100 \mathrm{ml}$ methanol by shaking at $80 \mathrm{rpm}$ for $24 \mathrm{~h}$ at RT. Next, the macerates were filtered, first through Whatman filter paper \#4 and then through a Nylon membrane $0.45 \mu \mathrm{m}$ pore size. Finally, $4 \mathrm{ml}$ of the filtrates was distributed into amber vials, the solvent was evaporated using a nitrogen evaporator (Mini-Vap, CRS, Louisville, USA), the vial was weighed, and the precipitate was resuspended in $1 \mathrm{ml}$ methanol. All samples were stored at $4^{\circ} \mathrm{C}$ until use.

2.2. Molecular Identification through DNA Barcoding. DNA barcoding is a molecular method which allows the rapid, accurate, and automatic identification of plants using DNA sequences. This method has been tested in numerous plant species and has been proposed as an alternative for the authentication of medicinal plants $[35,36]$. First, plant powder was obtained as described above, and $100 \mathrm{mg}$ from each sample was used for DNA isolation using the PureLink Plant Total DNA Purification Kit (Invitrogen, Carlsbad, USA), following the protocol suggested by the manufacturer. To test the quality of isolated DNA, a $5 \mu \mathrm{l}$ sample was run on a $0.8 \%$ agarose gel stained with EvaGreen (Jena Bioscience, Jena, Germany). Quantification of DNA was achieved by UV spectrophotometry using a NanoDrop 2000 Spectrophotometer (Thermo Fisher Scientific, Waltham, USA). Primers and PCR conditions were as those reported by the Consortium for Barcode of Life (CBOL) Plant Working Group [35]. Primers used for amplification of matK gene were 3F-KIM-F $\left(5^{\prime}\right.$ CGT ACA GTA CTT TTG TGT TTA CGA G-3 ${ }^{\prime}$ ) and 1RKIM-R ( $5^{\prime}$-ACC CAG TCC ATC TGG AAA TCT TGG TTC- $3^{\prime}$ ), and for amplification of $r b c L$ gene primers rbcLaF $\left(5^{\prime}\right.$-ATG TCA CCA CAA ACA GAG ACT AAA GC$\left.3^{\prime}\right)$ and rbcLa-R (5'-GTA AAA TCA AGT CCA CCR CG$\left.3^{\prime}\right)$ were used. Amplification reactions were performed in a final volume of $20 \mu \mathrm{l}$ containing $20 \mathrm{mM}$ Tris- $\mathrm{HCl}(\mathrm{pH} \mathrm{8.4})$, $50 \mathrm{mM} \mathrm{KCl}, 2 \mathrm{mM} \mathrm{MgCl}, 0.2 \mathrm{mM}$ dNTPs mix, $1 \mu \mathrm{M}$ each primer, $10 \mathrm{ng}$ of genomic DNA and 2 units of Taq DNA polymerase (Jena Bioscience, Jena, Germany). Amplifications were performed in a Multigene Thermocycler (Labnet International, Edison, USA) using the program: 1 step at $94^{\circ} \mathrm{C}$ for $5 \mathrm{~min}, 35$ cycles consisting of $30 \mathrm{~s}$ at $94^{\circ} \mathrm{C}, 1 \mathrm{~min}$ at $52^{\circ} \mathrm{C}$, and $1 \mathrm{~min}$ at $72^{\circ} \mathrm{C}$ and a final extension step of $5 \mathrm{~min}$ at $72^{\circ} \mathrm{C}$. Amplification products were separated by electrophoresis in $0.8 \%$ agarose gels and stained with EvaGreen. The PCR products were purified using the GenElute PCR Clean-Up Kit (Sigma-Aldrich, St. Louis, USA) following the manufacturer's instructions. The DNA concentration of the samples was again estimated using a NanoDrop Spectrophotometer and PCR products were sent for sequencing to the Genomic Services Laboratory at Langebio-Cinvestav (Irapuato, Mexico). DNA sequences were used for plant identification through the Identification Engine at the Barcode of Life Data System (http://www.boldsystems.org) and were submitted to the public sequence repository GenBank.

2.3. Phytochemical Characterization. Only plants or parts of them, which have not been analysed previously, were phythochemically characterized [37]: fine plant powder was suspended at $100 \mathrm{mg} / \mathrm{ml}$ in distilled water with shaking $(80 \mathrm{rpm})$ overnight at RT in the dark and subsequently centrifuged $(2 \mathrm{~min}, 10,000 \times \mathrm{g})$.

Flavonoids. $1 \mathrm{ml}$ supernatant, diluted with $900 \mu \mathrm{l}$ distilled water, was mixed with $5 \mathrm{ml} 1 \% \mathrm{NH}_{4} \mathrm{Cl}$ and then filtered. Afterwards, 5 drops of concentrated $\mathrm{H}_{2} \mathrm{SO}_{4}$ were added. An unstable yellow colour is formed in the presence of flavonoids.

Tannins. $1 \mathrm{ml}$ supernatant was boiled for $2 \mathrm{~min}$ and then 5 drops of $0.1 \% \mathrm{FeCl}_{3}$ were added. A brownish green or blue black colour indicates the presence of tannins.

Terpenoids. $100 \mu \mathrm{l}$ methanolic plant extract, diluted with $5 \mathrm{ml}$ methanol, was mixed with $2 \mathrm{ml}$ dichloromethane and then 
TABLE 2: Qualitative phytochemical analysis of 4 studied extracts: ++, present; +, slightly present; and -, not present.

\begin{tabular}{lcccc}
\hline Extract & Flavonoids & Tannins & Terpenoids & Saponins \\
\hline ESM & ++ & ++ & ++ & + \\
CsM & + & ++ & + & + \\
CsFM & + & ++ & ++ & + \\
HsM & + & ++ & + & ++ \\
\hline
\end{tabular}

$3 \mathrm{ml}$ concentrated $\mathrm{H}_{2} \mathrm{SO}_{4}$ was added. After 20 min a stable layer was formed and a reddish-brown colour in the interface indicates positive results for terpenoids.

Saponins. $5 \mathrm{ml}$ supernatant was boiled for $2 \mathrm{~min}$, diluted with distilled water, and shaken to form foam; then 3 drops of olive oil were added and again shaken vigorously. The formation of an emulsion indicates the presence of saponins.

2.4. Antimicrobial Assays. The following microorganisms were acquired from ATCC: Bacillus cereus \#49064, Enterococcus faecalis \#29212, Klebsiella pneumoniae \#10031, Salmonella typhimurium \#29630, Streptococcus pyogenes \#19615 and the following are obtained from the Microbiology Laboratory collection (CUCI, University of Guadalajara): Escherichia coli, Proteus mirabilis, Pseudomonas aeruginosa, Serratia marcescens, and Staphylococcus aureus [38]. Agar plates with Lysogeny Broth (LB; MP Biomedicals, Santa Ana, USA) or Müller-Hinton (MH; MP Biomedicals, Santa Ana, USA) were inoculated with $10^{7} \mathrm{cfu}$ of the model organism. Sterile sensidiscs ( $6 \mathrm{~mm}$ diameter) were impregnated with $2 \mu \mathrm{l}$ and $10 \mu \mathrm{l}$ extract (20-80 mg/ml), $2 \mu \mathrm{l}$ chloramphenicol (Cm, $25 \mathrm{mg} / \mathrm{ml}$; Sigma-Aldrich, St. Louis, USA) was used as positive control, and $10 \mu \mathrm{l}$ methanol was used as mock control. After their incubation at $37^{\circ} \mathrm{C}$ for $24 \mathrm{~h}$ the diameter of the inhibition zone was measured (Kirby-Bauer method). For extracts with positive results the minimal inhibitory concentration (MIC) was determined using 96-well microtiter plates (MTP): all wells contained $50 \mu \mathrm{l}$ medium and were serially diluted starting with $50 \mu \mathrm{l}$ extract (or control) in the first row; finally all wells were inoculated with $50 \mu \mathrm{l}$ medium adjusted to 0.5 McFarland (approx. $10^{8} \mathrm{cfu} / \mathrm{ml}$ ). The MTPs were incubated at $37^{\circ} \mathrm{C}$ for $24 \mathrm{~h}$ and the growth was measured by absorption at $625 \mathrm{~nm}$ with an ELISA-reader (Multiskan FC, Thermo Fisher Scientific, Waltham, USA). All tests were done six times.

2.5. Cell Line and Culturing Conditions. The cell line Caco2 (ATCC, Manassas, USA) was grown in DMEM/F12 (Caisson, Smithfield, USA) supplemented with 10\% FBS (Biowest, Kansas City, USA) at $37^{\circ} \mathrm{C}, 4 \% \mathrm{CO}_{2}$, and $95 \% \mathrm{RH}$. Experiments were carried out in 96-well MTP containing $100 \mu \mathrm{l}$ medium inoculated with $10^{4}$ cells. After $24 \mathrm{~h}$ incubation for cell attachment $100 \mu \mathrm{l}$ of methanolic plant extract (40-60 mg/ml) or control (methanol or $\mathrm{H}_{2} \mathrm{O}_{2}$ ) was added and serially diluted $1: 2$. Afterwards, the cells were incubated for additional $24 \mathrm{~h}$ before the analysis. For qualitative assays $1.5 * 10^{5}$ cells were grown in $1 \mathrm{ml}$ medium in 12-well MTP on cover slides and otherwise using the same culturing conditions.
2.6. Cell Viability and Necrosis Induction. To determine the metabolic activity the old medium was removed, the cells were washed twice with phosphate buffered saline (PBS), and $100 \mu \mathrm{l}$ medium containing $2 \mu \mathrm{l}$ WST-1 was added. After incubating for $4 \mathrm{~h}$ absorbance at $440 \mathrm{~nm}$ was measured with an ELISA-reader (Multiskan FC). Neutral red uptake (NRU) and trypan blue assays were made in 12-well MTP and the cells were grown on cover slides. After the last $24 \mathrm{~h}$ of incubation $20 \mu \mathrm{l}$ of $0.33 \%$ neutral red solution (Santa Cruz, Santa Cruz, USA) was added into each well and incubated for additional $4 \mathrm{~h}$. Afterwards, the cover slides were washed once with PBS and observed under the microscope (Axioskop 40FL, Zeiss, Oberkochen, Germany). To detect necrosis, 0.05\% (final concentration) trypan blue (Biowest) was added and incubated for 5 to $10 \mathrm{~min}$ and the cover slides were washed with PBS and then observed under the microscope (Zeiss Axioskop 40FL). All tests were done in triplicate.

2.7. Statistical Analysis. Values are expressed as means \pm 1.96 * standard error of mean (1.96 * SEM). Differences between groups were determined by one-way analysis of variance (ANOVA) and subjected post hoc to Tukey's HSD multiple comparison tests using the program Origin 5.0 (Microcal Software, Northampton, USA). A value of $p<0.05$ was considered to indicate statistical significance. The half maximal cytotoxic concentration $\left(\mathrm{CC}_{50}\right)$ was calculated by nonlinear curve fit with dose-response function using the program Origin 5.0.

\section{Results}

3.1. Phytochemical Analysis. Methanolic extracts from different parts of $A$. adstringens, $C$. ambrosioides, C. mexicanum, E. carlinae, and $P$. dulce were prepared at concentrations ranging from 20 to $80 \mathrm{mg} / \mathrm{ml}$ and designated by the abbreviations shown in Table 1.

As many reports on the composition of A. adstringens, $C$. ambrosioides, and $P$. dulce are already published elsewhere, those were not analysed here. Thus, the phytochemical composition of four extracts that have not yet been characterized was determined qualitatively (Table 2). This analysis revealed that the fruits of C. ambrosioides do not contain saponins.

3.2. Molecular Identification. All plants collected in the wild were identified through PCR amplification and DNA sequencing of regions of $r b c L$ and matK plastid genes, which have been proposed as the core plant barcode [35]. For $r b c L$ fragments, the DNA sequence length was between 527 and 529 bases, while the sequence length of matK was 
TABLE 3: Molecular identification of the collected medicinal plants through DNA barcoding.

\begin{tabular}{|c|c|c|c|c|}
\hline Plant sample & DNA barcode & GenBank ID & Top scores & $\%$ similarity \\
\hline \multirow{6}{*}{$\begin{array}{l}\text { Chenopodium ambrosioides } \\
\text { (Dysphania ambrosioides) }\end{array}$} & \multirow{3}{*}{$r b c L$} & \multirow{3}{*}{ MG436873 } & D. ambrosioides & 100.00 \\
\hline & & & D. multifida & 100.00 \\
\hline & & & C. album & 99.62 \\
\hline & \multirow{3}{*}{$\operatorname{matK}$} & \multirow{3}{*}{ MG572013 } & D. ambrosioides & 100.00 \\
\hline & & & C. acuminatum & 99.88 \\
\hline & & & D. multifida & 99.74 \\
\hline \multirow{6}{*}{ Cirsium mexicanum } & \multirow{3}{*}{$r b c L$} & \multirow{3}{*}{ MG436872 } & C. mexicanum & 100.00 \\
\hline & & & C. undulatum & 100.00 \\
\hline & & & C. scariosum & 100.00 \\
\hline & \multirow{3}{*}{ matK } & \multirow{3}{*}{ MG572012 } & C. discolor & 100.00 \\
\hline & & & C. altissimum & 100.00 \\
\hline & & & C. horridulum & 100.00 \\
\hline \multirow{4}{*}{ Eryngium carlinae } & \multirow{3}{*}{$r b c L$} & \multirow{3}{*}{ MG436874 } & E. aristulatum & 99.81 \\
\hline & & & E. pendletonense & 99.81 \\
\hline & & & E. leavenworthii & 99.62 \\
\hline & matK & No data & No data & No data \\
\hline \multirow{6}{*}{ Pithecellobium dulce } & \multirow{3}{*}{$r b c L$} & \multirow{3}{*}{ MG436875 } & P. dulce & 100.00 \\
\hline & & & P. lanceolatum & 99.43 \\
\hline & & & Acacia centralis & 99.43 \\
\hline & \multirow{3}{*}{ matK } & \multirow{3}{*}{ MG572014 } & P. dulce & 100.00 \\
\hline & & & P. lanceolatum & 100.00 \\
\hline & & & Havardia mexicana & 99.25 \\
\hline
\end{tabular}

TABLE 4: Antibacterial activity of methanolic extract from Chenopodium ambrosioides fruits (ESM) compared to chloramphenicol (Cm). Values expressed as mean $\pm 1.96 * \operatorname{SEM}(n=3)$ of the inhibition halo in $\mathrm{mm}$.

\begin{tabular}{lccc}
\hline Microorganism & \multicolumn{2}{c}{$\begin{array}{c}\text { Zone of growth inhibition }[\mathrm{mm}] \\
\text { Cm }(2 \mu \mathrm{l}, 50 \mathrm{mg} / \mathrm{ml})\end{array}$} & $\begin{array}{c}\text { Statistical } \\
\text { significance }\end{array}$ \\
\hline Enterococcus faecalis & ESM $(10 \mu \mathrm{l}, 70 \mathrm{mg} / \mathrm{ml})$ & $22.0 \pm 1.1$ & $p=0.003$ \\
Salmonella typhimurium & $13.3 \pm 2.4$ & $37.3 \pm 3.5$ & $p=4.8 * 10^{-4}$ \\
Escherichia coli & $18.0 \pm 1.1$ & $26.3 \pm 2.4$ & $p=3.2 * 10^{-4}$ \\
\hline
\end{tabular}

between 807 and 813 bases. For similarity searches, these sequences were submitted to the Barcode of Life Data Systems (http://www.boldsystems.org/) using the Plant Identification tool and plant species showing that the top matching scores are depicted in Table 3 along with the corresponding GenBank accession numbers for the DNA sequences obtained in this work. Despite several attempts, the $m a t K$ primers failed to amplify the DNA from E. carlinae; thus identification of this plant could only be achieved using $r b c L$ sequence. It must be noticed, however, that at the moment neither the matK nor the $r b c L$ sequences for E. carlinae are available at the Barcode of Life Data System, and hence the best matches were closely related species. A. adstringens has been identified earlier [38].

3.3. Antimicrobial Activity. In the screening for antimicrobial activity by the Kirby-Bauer method only the fruit extract from $C$. ambrosioides caused a clear zone of inhibition against the three strains of E. faecalis, S. typhimurium, and E. coli; as expected, the raw extract ESM had a significant
TABLE 5: Minimal inhibitory concentration (MIC) for methanolic extract from Chenopodium ambrosioides fruits (ESM) compared to chloramphenicol $(\mathrm{Cm})$.

\begin{tabular}{lcc}
\hline Microorganisms & $\begin{array}{c}\text { Minimal inhibitory concentration } \\
\text { (MIC) }[\mu \mathrm{g} / \mathrm{ml}]\end{array}$ \\
& ESM & $\mathrm{Cm}$ \\
\hline Enterococcus faecalis & 4375 & 6 \\
Salmonella typhimurium & 137 & 6 \\
Escherichia coli & 1094 & 6 \\
\hline
\end{tabular}

lower activity than a pure antibiotic (Table 4). Hence, only these combinations were subjected to a MIC determination (Table 5). None of the other extracts showed any effect on the tested bacterial strains.

3.4. Cytotoxicity. The cytotoxicity of the extracts on the enterocyte cell line Caco-2 was estimated by the reduction 


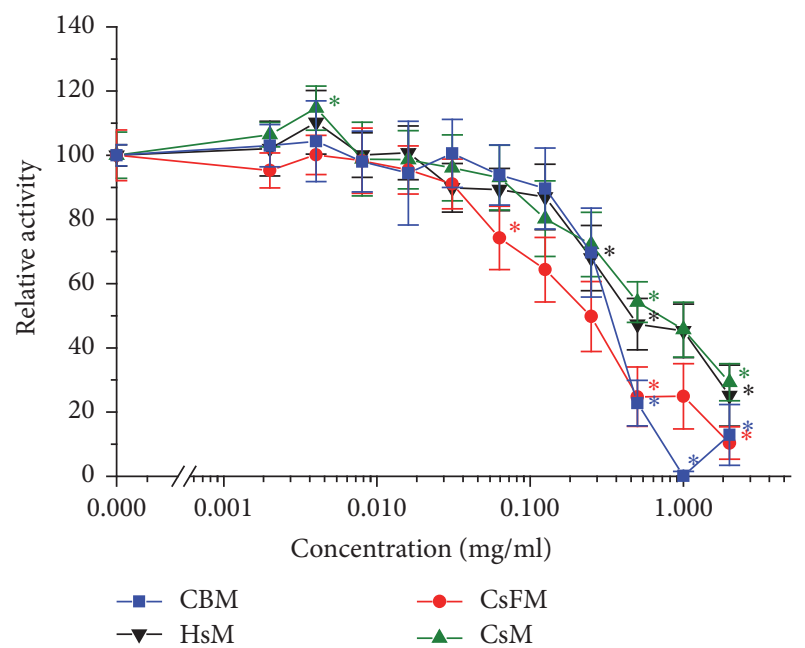

FIgUre 1: Cytotoxicity of methanolic extracts on the cell line Caco2: bark of $A$. adstringens (CBM, square), whole plant of E. carlinae (HsM, down triangle), and flower (CsFM, circle) and whole plant (CsM, up triangle) of C. mexicanum. Error bars indicate $1.96 *$ SEM $(n=6) ; *$ indicates statistically significant difference to control and to the next smaller value $(p<0.05)$.

of the tetrazolium salt WST by dehydrogenase activity. Most of the tested methanolic plant extracts had a cytotoxic concentration of $\mathrm{CC}_{50} \geq 250 \mu \mathrm{g} / \mathrm{ml}$, which are considered low cytotoxicity values: the bark of $A$. adstringens (CBM) with $\mathrm{CC}_{50}=342 \pm 38 \mu \mathrm{g} / \mathrm{ml}$, flowers (CsFM) and whole plant (CsM) of C. mexicanum with $\mathrm{CC}_{50}=250 \pm 55 \mu \mathrm{g} / \mathrm{ml}$ and with $\mathrm{CC}_{50}=323 \pm 93 \mu \mathrm{g} / \mathrm{ml}$, respectively, and the whole plant of $E$. carlinae (HsM) with $\mathrm{CC}_{50}=356 \pm 114 \mu \mathrm{g} / \mathrm{ml}$ (Figure 1). While for $P$. dulce the bark extract (GBM) was not cytotoxic either with $\mathrm{CC}_{50}=347 \pm 78 \mu \mathrm{g} / \mathrm{ml}$, its leaf extract (GLM) exhibited first signs of cytotoxicity with a $\mathrm{CC}_{50}=126 \pm 14 \mu \mathrm{g} / \mathrm{ml}$. This contrast between different parts of a plant was even more pronounced for the $C$. ambrosioides extracts: while the leaf extract (ELM) was the least cytotoxic with $\mathrm{CC}_{50}=563 \pm$ $66 \mu \mathrm{g} / \mathrm{ml}$, the fruit extract (ESM) was the most cytotoxic one with $\mathrm{CC}_{50}=45 \pm 7 \mu \mathrm{g} / \mathrm{ml}$ (Figure 2).

These results were confirmed qualitatively by neutral red uptake (NRU), where functional lysosomes are stained red and trypan blue staining (TBS), where necrotic cells with disrupted membranes are stained blue. At $400 \mu \mathrm{g} / \mathrm{ml}$ of CBM, Caco- 2 cells started to show irregular shapes, although the confluence was not reduced and most cells still had functional lysosomes (i.e., red by NRU, Figure 3(a)) and membranes. At $800 \mu \mathrm{g} / \mathrm{ml}$ of CBM the confluence was clearly reduced and the cells had only a faint red staining by NRU (not shown) and most were blue by TBS (not shown). CsM at $400 \mu \mathrm{g} / \mathrm{ml}$ caused no observable changes in confluence, cell shape, membrane functionality (not shown), and lysosome functionality (Figure 3(b)) and even at a much higher concentration of $2,000 \mu \mathrm{g} / \mathrm{ml}$ of CsM most cells were still stained red by NRU, although the confluence was clearly reduced (not shown). The extract CsFM at $480 \mu \mathrm{g} / \mathrm{ml}$ caused no observable changes in confluence, cell shape, membrane functionality (not shown), and lysosome functionality (Figure 3(c)); but at $1,200 \mu \mathrm{g} / \mathrm{ml}$

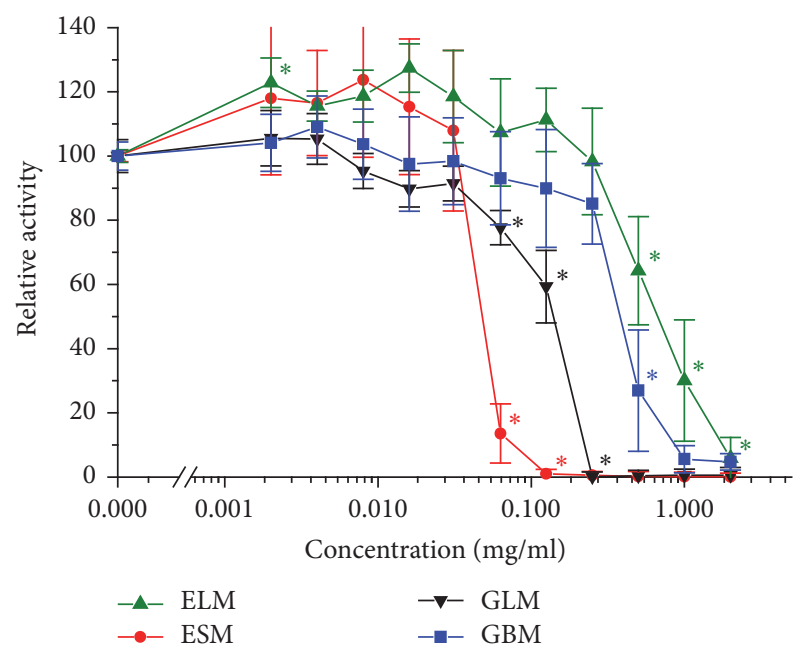

Figure 2: Cytotoxicity of methanolic extracts on the cell line Caco2: leaf (ELM, up triangle) and fruit (ESM, circle) of C. ambrosioides as well as leaf (GLM, down triangle) and bark (GBM, square) of $P$. dulce. Error bars indicate $1.96 * \operatorname{SEM}(n=6) . *$ indicates statistically significant difference to control and to the next smaller value $(p<$ $0.05)$.

of CsFM confluence was clearly reduced and several cells were stained blue by TBS while by NRU the cells were not stained or only slightly red (not shown). The extract HsM at $500 \mu \mathrm{g} / \mathrm{ml}$ did not cause observable cellular alterations; that is, the confluence did not decrease and the cells had functional membranes (not shown) and functional lysosomes (red by NRU, Figure 3(d)), similar to the negative control (Figure 3(e)). At 1,500 $\mu \mathrm{g} / \mathrm{ml}$ of HsM the red staining of the cells by NRU was fainter (not shown) but at $3,000 \mu \mathrm{g} / \mathrm{ml}$ of HsM the confluence was clearly reduced and the cells were not stained red by NRU but blue by TBS (both not shown).

Even though $500 \mu \mathrm{g} / \mathrm{ml}$ of ELM reduced the confluence of Caco-2 strongly, the cells were disintegrated and the lysosomes were not stained by NRU (Figure 4(a)), while at $250 \mu \mathrm{g} / \mathrm{ml}$ of ELM only the confluence was reduced but the lysosomes were still functional (not shown). In contrast, the extract from its fruits (ESM) at $20 \mu \mathrm{g} / \mathrm{ml}$ reduced slightly confluence; at $50 \mu \mathrm{g} / \mathrm{ml}$ of ESM confluence was clearly reduced and the cells were deformed and barely stained by NRU (Figure 4(b)) and many cells were stained blue by TBS (not shown). At higher concentrations $(\geq 100 \mu \mathrm{g} / \mathrm{ml}$ ESM) only cell debris could be observed (not shown; similar to the positive control Figure 3(f)). This cytotoxic effect was already seen after $4 \mathrm{~h}$ of exposure (not shown). GBM at $400 \mu \mathrm{g} / \mathrm{ml}$ diminished confluence and the cells were not stained red by NRU (Figure 4(c)); GLM at $100 \mu \mathrm{g} / \mathrm{ml}$ diminished lysosomal functionality only slightly (Figure $4(\mathrm{~d})$ ) and cells were not stained blue by TBS (not shown), but already at $200 \mu \mathrm{g} / \mathrm{ml}$ of GLM the cell membrane was disrupted (not shown) and lysosomes were not functional anymore (not shown).

\section{Discussion}

The methanolic extracts were evaluated against ten bacterial strains; three of them were Gram-positive and seven 


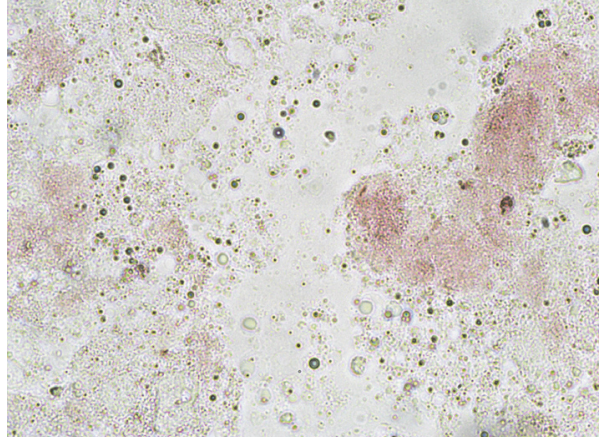

(a)

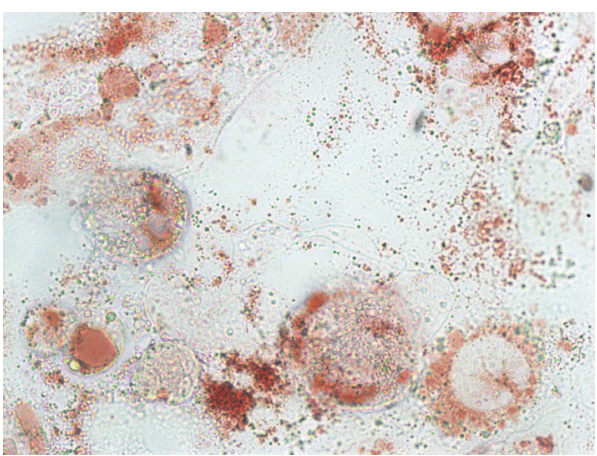

(c)

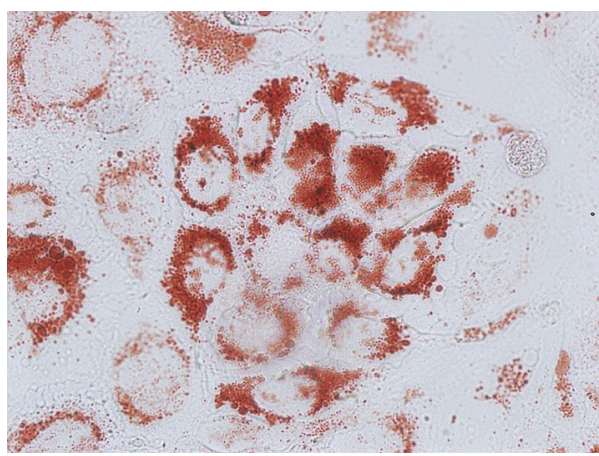

(e)

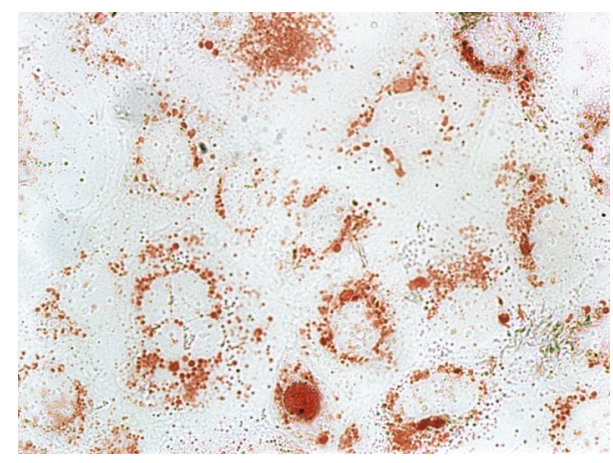

(b)

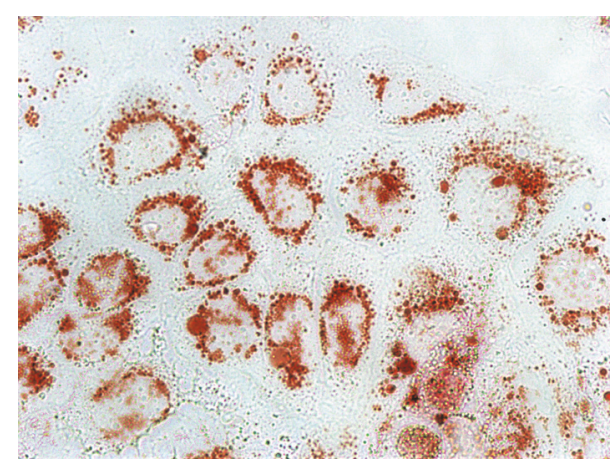

(d)

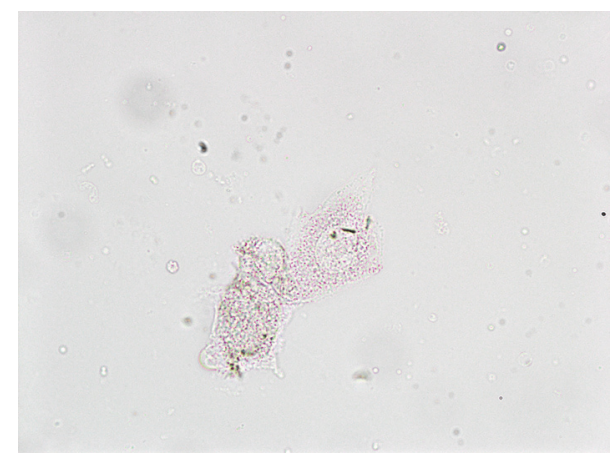

(f)

Figure 3: Neutral red uptake of Caco-2 after $24 \mathrm{~h}$ exposure to different methanolic extracts: (a) bark of $A$. adstringens (400 $\mu \mathrm{g} / \mathrm{ml}$ CBM); (b) whole plant of C. mexicanum ( $400 \mu \mathrm{g} / \mathrm{ml} \mathrm{CsM}$ ); (c) flowers of C. mexicanum ( $480 \mu \mathrm{g} / \mathrm{ml} \mathrm{CsFM);} \mathrm{(d)} \mathrm{whole} \mathrm{plant} \mathrm{of} \mathrm{E.} \mathrm{carlinae} \mathrm{(500} \mu \mathrm{g} / \mathrm{ml}$ $\mathrm{HsM}$ ). (e) Methanol as negative control and (f) $\mathrm{H}_{2} \mathrm{O}_{2}$ as positive control.

Gram-negative and all of them are of clinical interest. The cell line used was Caco-2 (human epithelial colorectal adenocarcinoma) in order to elucidate possible antitumoral effects.

Amphipterygium adstringens. The methanolic raw extract of the bark of $A$. adstringens (CBM) was cytotoxic for the cell line Caco-2 at a concentration of $\mathrm{CC}_{50}=342 \pm 38 \mu \mathrm{g} / \mathrm{ml}$, which is in a similar range of observed cytotoxic effects of an aqueous (CBW) and an ethanolic bark (CBE) extract on HeLa with a $\mathrm{CC}_{50}=467 \mu \mathrm{g} / \mathrm{ml}$ and $\mathrm{CC}_{50}=202 \mu \mathrm{g} / \mathrm{ml}$, respectively [38]. It was previously shown that the bark contains anacardic acids [39], and those compounds were cytotoxic to several cell lines at concentrations of $10-40 \mu \mathrm{M}(\approx 3.4-13.6 \mu \mathrm{g} / \mathrm{ml})$ $[27,40]$; as the cytotoxicity increased with decreasing polarity of the solvent, it is reasonable that those lipophilic anacardic acids are the cytotoxic principle for the cell line Caco-2 as well. Also Rodriguez-Garcia et al. (2015) found antiproliferative effects by a methanolic bark extract (CBM) on human cell lines like OVCAR-3, UACC-62, HT-29, PC-3, U251, NCI$\mathrm{H} 460$, and $786-\mathrm{O}$ ranging from 4.4 to $28.0 \mu \mathrm{g} / \mathrm{ml}$ [41]. On the other hand, Xiu et al. (2014) showed that anacardic acids promote proliferation of ovarian cancer cells, inhibit late apoptosis, and induce cell migration by lamellipodia formation [42]. Surprisingly, our CBM extract did not inhibit bacterial growth, although we found that an ethanolic extract (CBE) inhibited the growth of B. cereus $(150 \mu \mathrm{g} / \mathrm{ml})$, E. faecalis $(660 \mu \mathrm{g} / \mathrm{ml})$, and S. aureus $(1,380 \mu \mathrm{g} / \mathrm{ml})$ [38]. Canales et al. (2005) reported that an methanolic extract inhibited Sarcina 


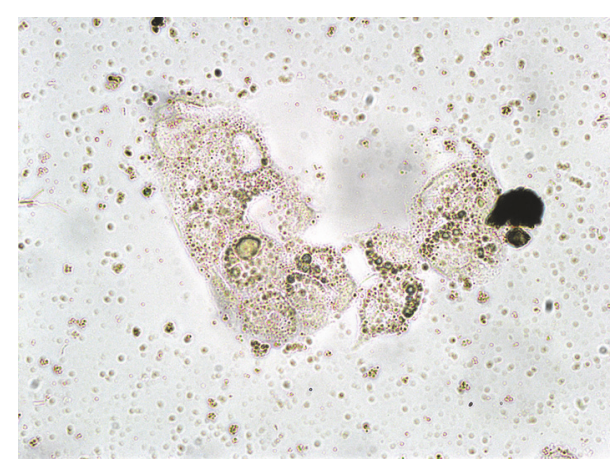

(a)

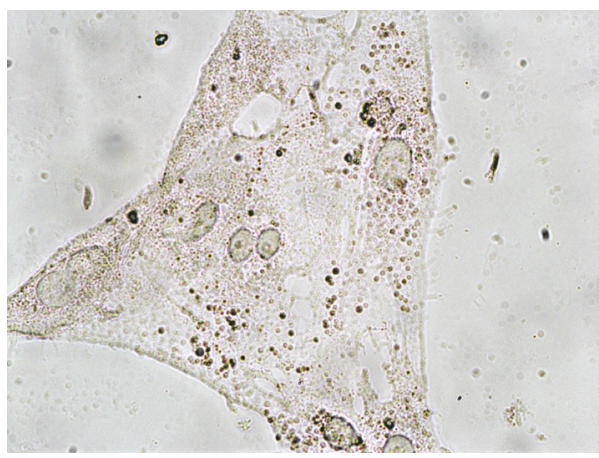

(c)

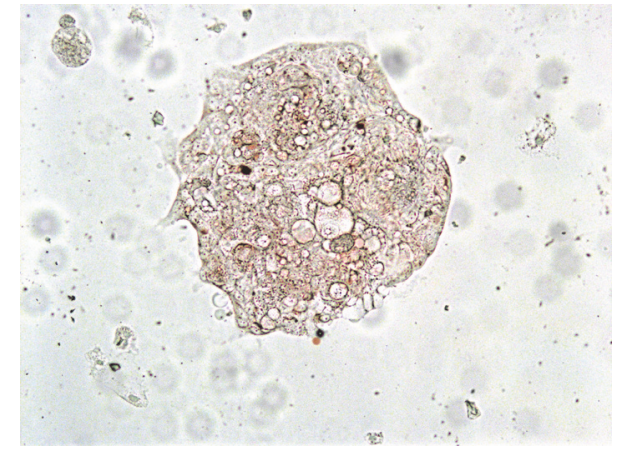

(b)

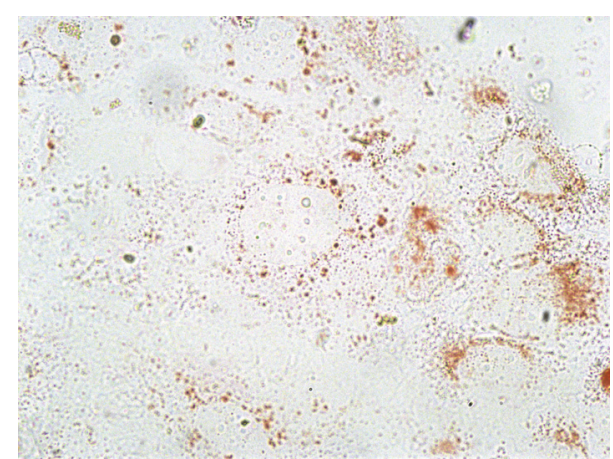

(d)

FIGURE 4: Neutral red uptake of Caco-2 after 24 h exposure to different methanolic extracts: (a) leaves from C. ambrosioides (500 $\mu \mathrm{g} / \mathrm{ml}$ ELM); (b) fruits from C. ambrosioides (50 $\mu \mathrm{g} / \mathrm{ml} \mathrm{ESM);} \mathrm{(c)} \mathrm{bark} \mathrm{of} \mathrm{P.} \mathrm{dulce} \mathrm{(400 \mu g/ml} \mathrm{GBM);} \mathrm{(d)} \mathrm{leaves} \mathrm{from} \mathrm{P.} \mathrm{dulce} \mathrm{(100} \mu \mathrm{g} / \mathrm{ml} \mathrm{GLM).}$

lutea $(125 \mu \mathrm{g} / \mathrm{ml})$, S. aureus $(250 \mu \mathrm{g} / \mathrm{ml})$, and B. subtilis $(1,500 \mu \mathrm{g} / \mathrm{ml})$ [43], although Rodriguez-Garcia et al. (2015) reported only an effective inhibition of Streptococcus mutans $(125 \mu \mathrm{g} / \mathrm{ml} \mathrm{CBM})$ while other bacteria are only inhibited at very high concentrations ( $>37 \mathrm{mg} / \mathrm{ml} \mathrm{CBM})$ [41]. This apparent contradiction may be explained by the fact that the degree of unsaturation of the fatty acid of anacardic acids has a high impact on their antimicrobial activity [44].

Cirsium mexicanum. To the best of our knowledge, there are no scientific reports on the biological activity of extracts from C. mexicanum, so we report here for the first time that extracts from the whole plant as well as from the flowers of this species contain potentially active molecules, mainly tannins and saponins, and, in contrast to the whole plant, the flowers contained also terpenoids; flavonoids were barely detectable in both extracts. Using the Kirby-Bauer test, no antibacterial activity could be detected and low cytotoxicity was observed for both methanolic extracts with $323 \pm 93 \mu \mathrm{g} / \mathrm{ml} \mathrm{CsM}$ and $250 \pm 55 \mu \mathrm{g} / \mathrm{ml} \mathrm{CsFM}$, respectively. The latter results could be confirmed qualitatively by NRU and TBS. These results do not indicate this plant as a good candidate for anticancer treatment as it is used empirically by the Mexican population [14].

Eryngium carlinae. On the composition and biological activity of extracts from E. carlinae few scientific reports exist only: for the aerial parts of some Eryngium species it is known that they contain mainly saponins, flavonoids, and essential oils [45]; here we report for the first time a qualitative phytochemical analysis for the species E. carlinae: saponins and tannins were abundant; flavonoids and terpenoids were hardly detectable. While Castillo-Juárez et al. (2009) reported that a methanolic extract inhibited H. pylori [16], we could not find bacterial inhibition using the Kirby-Bauer method. A similar result was found for methanolic extracts from leaves of E. foetidum, which is also native to Mexico and South America: one group reported inhibition of H. pylori, while another group found no inhibition of several other bacterial strains (reviewed in [45]). To our knowledge, here we report for the first time cytotoxicological results on $E$. carlinae: we found with $356 \pm 114 \mu \mathrm{g} / \mathrm{ml} \mathrm{HsM}$ low cytotoxic effects on Caco-2. Until now, only for few triterpenoids and triterpenoid-glycosides, isolated from different Eryngium species, there are reports about their moderate antiproliferative activity on different human cell lines [45].

Pithecellobium dulce. Kumar and Nehra (2014) found antibacterial activity for a methanolic bark extract from $P$. dulce against E. faecalis, E. coli, K. pneumoniae, M. luteus, S. typhimurium, and S. epidermidis at MICs of 250-500 $\mu \mathrm{g} / \mathrm{ml}$ [46] and the same group reported inhibition of bacterial growth for a methanolic leaf extract against $B$. subtilis, E. aerogenes, $E$. coli, K pneumoniae, P. aeruginosa, and S. epidermidis at MICs ranging from 375 to $1000 \mu \mathrm{g} / \mathrm{ml}$ [47]. We were not able to detect bacterial inhibition using the Kirby-Bauer test, from 
both extracts, but we found a cytotoxic effect on Caco-2 with $\mathrm{CC}_{50}=347 \pm 78 \mu \mathrm{g} / \mathrm{ml}$ for the bark extract $(\mathrm{GBM})$ and the methanolic leaf extract (GLM) was even more cytotoxic with a $\mathrm{CC}_{50}=126 \pm 14 \mu \mathrm{g} / \mathrm{ml}$. This is in a similar range of $\mathrm{CC}_{50}=112 \mu \mathrm{g} / \mathrm{ml}$ GLM for the cell line MCF-7 [48], a value also reported by Olmedo-Agudo et al. (2016) with $\mathrm{CC}_{50}>$ $100 \mu \mathrm{g} / \mathrm{ml} \mathrm{GLM} \mathrm{[21];} \mathrm{the} \mathrm{latter} \mathrm{group} \mathrm{determined} \mathrm{cytotoxicity}$ for the cell line $\mathrm{CaP}$ with $\mathrm{CC}_{50}=3.7 \mu \mathrm{g} / \mathrm{ml}$, indicating that $P$. dulce leaf extract has cytotoxic potential.

Chenopodium ambrosioides. The leaves of C. ambrosioides especially have been broadly studied, but the results vary strongly. While some authors find ascaridole and derivates with about $50-80.0 \%$ as the main component [33, 49-51], others find it with less than $10 \%$ as a minor component [52, 53]. It is supposed that, apart from the different geographic location, the part of the plant, or the processing method, those differences can be explained by the existence of different varieties of the plant: C. ambrosioides var. anthelminticum has a high ascaridole content while the other variety, var. pubescens, does not [54]. Sousa et al. (2012) could not detect antimicrobial activity from an ethanolic extract of the aerial parts up to $500 \mu \mathrm{g} / \mathrm{ml}$ [55], as we did not observe it either for a methanolic extract from the leaves. Jesus et al. (2017) determined for an ethanolic crude extract from leaves only very high MICs against Mycobacterium tuberculosis $(1.25 \mathrm{mg} / \mathrm{ml})$, E. faecalis $(4.29 \mathrm{mg} / \mathrm{ml})$, and $P$. aeruginosa $(68.75 \mathrm{mg} / \mathrm{ml})$ [56]. Generally, the whole aerial part is not considered (very) cytotoxic: Ruffa et al. (2002) did not detect cytotoxic effects up to $1,000 \mu \mathrm{g} / \mathrm{ml}$ for HepG2 [57], Koba et al. (2009) found a $\mathrm{CC}_{50}=700 \mu \mathrm{g} / \mathrm{ml}$ for $\mathrm{HaCaT}$ [50], and Barros et al. (2013) determined $\mathrm{CC}_{50}$ of 264 to $319 \mu \mathrm{g} / \mathrm{ml}$ for HeLa, HepG2, and HCT-15 [58]; those values are in the range of $\mathrm{CC}_{50}=563 \pm 66 \mu \mathrm{g} / \mathrm{ml}$ ELM that we report for Caco-2. Although Degenhardt et al. (2016) reported cytotoxic effects of an ethanolic leaf extract against blood cell lines with $\mathrm{CC}_{50}$ of 30-62 $\mu \mathrm{g} / \mathrm{ml}$ [33] and Al-kaf et al. (2016) reported a $\mathrm{CC}_{50} \approx$ $25 \mu \mathrm{g} / \mathrm{ml}$ for HT-29 for a hydrodistillate [51], both associated the cytotoxic effect to the high ascaridole content of their extracts, which coincide with a report on the cytotoxicity of ascaridoles with $\mathrm{CC}_{50}=4.2-23.7 \mu \mathrm{g} / \mathrm{ml}$ for different tumour cell lines [59]. However, Koba et al. (2009) could demonstrate that it is neither ascaridole $\left(\mathrm{CC}_{50}>1 \mathrm{mg} / \mathrm{ml}\right)$, as suspected, nor $p$-cymene $\left(\mathrm{CC}_{50}>1 \mathrm{mg} / \mathrm{ml}\right)$, but neral $\left(\mathrm{CC}_{50} \approx\right.$ $100 \mu \mathrm{g} / \mathrm{ml}$ ) is the cytotoxic principle [50]. Mainly we have analysed the parts of the plants commonly used to treat several disorders, including cancer, according to indigenous healers from Mexico; the only exception being the leaves from C. ambrosioides, which are preferred over their fruits. Here we report for the first time the cytotoxic properties of the methanolic fruit extract, being highly cytotoxic with a $\mathrm{CC}_{50}=45 \pm 7 \mu \mathrm{g} / \mathrm{ml}$, killing the cells by necrosis within about $4 \mathrm{~h}$. Moreover, we found also antibacterial properties of this extract being especially effective against $S$. typhimurium with a MIC of $137 \mu \mathrm{g} / \mathrm{ml}$ ESM. Only Ajaib et al. (2016) have reported inhibition zones of $20-30 \mathrm{~mm}$ in agar-diffusion tests against E. coli, S. aureus, $P$. aeruginosa, or $B$. subtilis by methanolic extracts from the fruits [32]. This makes the fruit extract of C. ambrosioides an interesting candidate for further studies on biological activity. A preliminary qualitative phytochemical analysis revealed the presence of flavonoids, tannins, and terpenoids and the absence of saponins.

\section{Conclusion}

This ethnopharmacological evaluation helps to direct the screening for plants with antitumoral properties. The most promising candidate resulted to be the methanolic extract of fruits from C. ambrosioides (ESM), followed by the methanolic leaf extract from $P$. dulce (GLM). In further studies the cytotoxic and antibacterial principle, especially from ESM, will be elucidated.

\section{Abbreviations}

MTP: Microtiter plate

NRU: Neutral red uptake

TBS: Trypan blue staining

CBM: Cuachalalate bark methanolic extract

CsFM: Cardosanto flower methanolic extract

CsM: Cardosanto aerial parts methanolic extract

ELM: Epazote leaf methanolic extract

ESM: Epazote fruit (seed) methanolic extract

GBM: Guamúchil bark methanolic extract

GLM: Guamúchil leaf methanolic extract

HsM: Hierba del sapo aerial parts methanolic extract.

\section{Conflicts of Interest}

The authors declare that there are no conflicts of interest regarding the publication of this paper.

\section{References}

[1] L.-F. Nothias, R. Knight, and P. C. Dorrestein, "Antibiotic discovery is a walk in the park," Proceedings of the National Acadamy of Sciences of the United States of America, vol. 113, no. 51, pp. 14477-14479, 2016.

[2] WHO, Global Action Plan on Antimicrobial Resistance, WHO, Geneva, Switzerland, 2015.

[3] R. I. Aminov, "A brief history of the antibiotic era: Lessons learned and challenges for the future," Frontiers in Microbiology, vol. 1, 2010.

[4] R. A. Mittermeier and C. Goettsch de Mittermeier, "La Importancia de la Diversidad Biológica de México," in México ante los Retos de la Biodiversidad, Sarukhán J. and R. Dirzo, Eds., pp. 1-14, Comisión Nacional para el Conocimineto y Uso de la Biodiversidad, Mexico, 1992.

[5] P. Muñetón-Pérez, "Plantas medicinales: un completo vital para la salud de los Mexicanos. Entrevista con el Dr. Erick Estrada Lugo," Revista Digital Universitaria (UNAM), vol. 10, no. 9, article 58, p. 9, 2009.

[6] A. Sharma, R. D. C. Flores-Vallejo, A. Cardoso-Taketa, and M. L. Villarreal, "Antibacterial activities of medicinal plants used in Mexican traditional medicine," Journal of Ethnopharmacology, vol. 208, pp. 264-329, 2017.

[7] A. J. Alonso-Castro, M. L. Villarreal, L. A. Salazar-Olivo, M. Gomez-Sanchez, F. Dominguez, and A. Garcia-Carranca, 
"Mexican medicinal plants used for cancer treatment: pharmacological, phytochemical and ethnobotanical studies," Journal of Ethnopharmacology, vol. 133, no. 3, pp. 945-972, 2011.

[8] A. Argueta, "Cuachalalate," Atlas de las Plantas de la Medicina Tradicional Mexicana, Universidad Autónoma de México (UNAM), 2017.

[9] H. Rosas-Acevedo, T. Terrazas, M. E. González-Trujano, Y. Guzmán, and M. Soto-Hernández, "Anti-ulcer activity of Cyrtocarpa procera analogous to that of Amphipterygium adstringens, both assayed on the experimental gastric injury in rats," Journal of Ethnopharmacology, vol. 134, no. 1, pp. 67-73, 2011.

[10] I. Oviedo-Chávez, T. Ramírez-Apan, M. Soto-Hernández, and M. Martínez-Vázquez, "Principles of the bark of Amphipterygium adstringens (Julianaceae) with anti-inflammatory activity," Phytomedicine, vol. 11, no. 5, pp. 436-445, 2004.

[11] A. Argueta, "Epazote," Atlas de las Plantas de la Medicina Tradicional Mexicana, Universidad Autónoma de México (UNAM), 2017.

[12] K. Song, J. Zhang, P. Zhang et al., "Five new bioactive compounds from Chenopodium ambrosioides," Journal of Asian Natural Products Research, vol. 17, no. 5, pp. 482-490, 2015.

[13] L. Trivellato-Grassi, A. Malheiros, C. Meyre-Silva et al., "From popular use to pharmacological validation: a study of the anti-inflammatory, anti-nociceptive and healing effects of Chenopodium ambrosioides extract," Journal of Ethnopharmacology, vol. 145, no. 1, pp. 127-138, 2013.

[14] E. Estrada-Muñiz, G. Guerrero-Palomo, and L. Vega, "Natural products: New anti-cancer agents derived from plants," Current Topics in Toxicology, vol. 8, pp. 19-32, 2012.

[15] R. Noriega-Cisneros, O. Ortiz-Vila, E. Esquivel-Gutiérrez et al., "Hypolipidemic activity of eryngium carlinae on streptozotocin-induced diabetic rats," Biochemistry Research International, vol. 2012, Article ID 603501, 5 pages, 2012.

[16] I. Castillo-Juárez, V. González, H. Jaime-Aguilar et al., "AntiHelicobacter pylori activity of plants used in mexican traditional medicine for gastrointestinal disorders," Journal of Ethnopharmacology, vol. 122, no. 2, pp. 402-405, 2009.

[17] A. Argueta, "Guamúchil," Atlas de las Plantas de la Medicina Tradicional Mexicana, Universidad Autónoma de México (UNAM), 2012.

[18] J. Megala and A. Geetha, "Antiulcerogenic activity of hydroalcoholic fruit extract of Pithecellobium dulce in different experimental ulcer models in rats," Journal of Ethnopharmacology, vol. 142, no. 2, pp. 415-421, 2012.

[19] S. Pradeepa, S. Subramanian, and V. Kaviyarasan, "Biochemical evaluation of antidiabetic properties of Pithecellobium dulce fruits studied in streptozotocin induced experimental diabetic rats," International Journal of Herbal Medicine, vol. 1, pp. 21-28, 2013.

[20] T. Sundarrajan, T. Rajkumar, E. Udhayakumar, and G. Arunachalam, "Hypolipidemic activity of Pithecellobium dulce Benth. in trition Wr-1339 induced hyperlilidemic rats," International Journal of Chemical and Pharmaceutical Science, vol. 1, pp. 50-53, 2010.

[21] D. A. Olmedo-Agudo, N. S. Marrone-Paredes, A. F. EspinosaRivas, C. P. Guerra-Torres, and M. P. Gupta, "Evaluación de la actividad antiprolifera de extractos metanólicos de plantas de la familia leguminosae," Revista Cubana de Plantas Medicinales, vol. 21, pp. 272-283, 2016.

[22] P. Cos, A. J. Vlietinck, D. V. Berghe, and L. Maes, "Anti-infective potential of natural products: how to develop a stronger in vitro proof-of-concept," Journal of Ethnopharmacology, vol. 106, no. 3, pp. 290-302, 2006.

[23] G. Brusotti, I. Cesari, A. Dentamaro, G. Caccialanza, and G. Massolini, "Isolation and characterization of bioactive compounds from plant resources: the role of analysis in the ethnopharmacological approach," Journal of Pharmaceutical and Biomedical Analysis, vol. 87, pp. 218-228, 2014.

[24] N. P. Sahu and S. B. Mahato, "Anti-inflammatory triterpene saponins of Pithecellobium dulce: Characterization of an echinocystic acid bisdesmoside," Phytochemistry, vol. 37, no. 5, pp. 1425-1427, 1994.

[25] L. Monzote, A. M. Montalvo, S. Almanonni, R. Scull, M. Miranda, and J. Abreu, "Activity of the essential oil from Chenopodium ambrosioides grown in Cuba against Leishmania amazonensis," Microbiology, vol. 52, no. 3, pp. 130-136, 2006.

[26] A. J. Alonso-Castro, J. R. Zapata-Morales, A. J. Ruiz-Padilla et al., "Use of medicinal plants by health professionals in Mexico," Journal of Ethnopharmacology, vol. 198, pp. 81-86, 2017.

[27] H. Huang, X. Hua, N. Liu et al., "Anacardic acid induces cell apoptosis associated with induction of ATF4-dependent endoplasmic reticulum stress," Toxicology Letters, vol. 228, no. 3, pp. 170-178, 2014.

[28] Y. Pollack, R. Segal, and J. Golenser, "The effect of ascaridole on the in vitro development of Plasmodium falciparum," Parasitology Research, vol. 76, no. 7, pp. 570-572, 1990.

[29] F. Kiuchi, Y. Itano, N. Uchiyama et al., "Monoterpene hydroperoxides with trypanocidal activity from Chenopodium ambrosioides," Journal of Natural Products, vol. 65, no. 4, pp. 509-512, 2002.

[30] E. Nibret and M. Wink, "Trypanocidal and cytotoxic effects of 30 ethiopian medicinal plants," Zeitschrift für Naturforschung C, vol. 66 c, pp. 541-546, 2011.

[31] R. Kumar, A. K. Mishra, N. K. Dubey, and Y. B. Tripathi, "Evaluation of Chenopodium ambrosioides oil as a potential source of antifungal, antiaflatoxigenic and antioxidant activity," International Journal of Food Microbiology, vol. 115, no. 2, pp. 159-164, 2007.

[32] M. Ajaib, T. Hussain, S. Farooq, and M. Ashiq, "Analysis of antimicrobial and antioxidant activities of Chenopodium ambrosioides: an ethnomedicinal plant," Journal of Chemistry, vol. 2016, Article ID 4827157, 11 pages, 2016.

[33] R. T. Degenhardt, I. V. Farias, L. T. Grassi et al., "Characterization and evaluation of the cytotoxic potential of the essential oil of Chenopodium ambrosioides," Revista Brasileira de Farmacognosia, vol. 26, no. 1, pp. 56-61, 2016.

[34] M. Singh, S. Khatoon, S. Singh, V. Kumar, A. K. S. Rawat, and S. Mehrotra, "Antimicrobial screening of ethnobotanically important stem bark of medicinal plants," Pharmacognosy Research, vol. 2, no. 4, pp. 254-257, 2010.

[35] CBOL Plant Working Group, "A DNA barcode for land plants," in Proceedings of the National Academy of Sciences of the United States of America, vol. 106, pp. 12794-12797, 2009.

[36] J. Marcial-Quino, J. A. Mendoza-Espinoza, and E. SierraPalacios, "DNA barcoding: An alternative for the identification of the medicinal plants employed in Mexico," Journal of Plant Sciences, vol. 10, no. 4, pp. 116-127, 2015.

[37] K. Thaipong, U. Boonprakob, K. Crosby, L. Cisneros-Zevallos, and D. Hawkins Byrne, "Comparison of ABTS, DPPH, FRAP, and ORAC assays for estimating antioxidant activity from guava fruit extracts," Journal of Food Composition and Analysis, vol. 19, no. 6-7, pp. 669-675, 2006. 
[38] Z. López, J. Villaruel-Muñoz, J. Rico, T. Terrasas, J. SalazarFlores, and P. Knauth, "Cytotoxic effects and antimicrobial activity of Cuachalalate (Amphipterygium adstringens) extracts as used in a traditional way," Journal of Chemical, Biological and Physical Science, vol. B5, pp. 1555-1565, 2015.

[39] I. Castillo-Juárez, F. Rivero-Cruz, H. Celis, and I. Romero, "Anti-Helicobacter pylori activity of anacardic acids from Amphipterygium adstringens," Journal of Ethnopharmacology, vol. 114, no. 1, pp. 72-77, 2007.

[40] Y.-A. Seong, P.-G. Shin, and G.-D. Kim, "Anacardic acid induces mitochondrial-mediated apoptosis in the A549 human lung adenocarcinoma cells," International Journal of Oncology, vol. 42, no. 3, pp. 1045-1051, 2013.

[41] A. Rodriguez-Garcia, I. T. A. Peixoto, M. J. Verde-Star, S. De La Torre-Zavala, H. Aviles-Arnaut, and A. L. T. G. Ruiz, "In Vitro Antimicrobial and Antiproliferative Activity of Amphipterygium adstringens," Evidence-Based Complementary and Alternative Medicine, vol. 2015, Article ID 175497, 7 pages, 2015.

[42] Y.-L. Xiu, Y. Zhao, W.-F. Gou, S. Chen, Y. Takano, and H.-C. Zheng, "Anacardic acid enhances the proliferation of human ovarian cancer cells," PLoS ONE, vol. 9, no. 6, Article ID 99361, p. 9, 2014.

[43] M. Canales, T. Hernández, J. Caballero et al., "Informant consensus factor and antibacterial activity of the medicinal plants used by the people of San Rafael Coxcatlán, Puebla, México," Journal of Ethnopharmacology, vol. 97, no. 3, pp. 429439, 2005.

[44] I. Kubo, H. Muroi, M. Himejima et al., "Structure-antibacterial activity relationships of anacardic acids," Journal of Agricultural and Food Chemistry, vol. 41, no. 6, pp. 1016-1019, 1993.

[45] S. A. Erdem, S. F. Nabavi, I. E. Orhan, M. Daglia, M. Izadi, and S. M. Nabavi, "Blessings in disguise: A review of phytochemical composition and antimicrobial activity of plants belonging to the genus Eryngium," DARU Journal of Pharmaceutical Sciences, vol. 23, no. 1, article no. 136, 2015.

[46] M. Kumar and K. Nehra, "Antimicrobial activity of crude extracts of Pithecellobium dulce bark against various human pathogenic microbes," World Journal of Pharmacy and Pharmaceutical Science, vol. 3, pp. 1244-1260, 2014.

[47] M. Kumar, K. Nehra, and J. S. Duhan, "Phytochemical analysis and antimicrobial efficacy of leaf extracts of Pithecellobium dulce," Asian Journal of Pharmaceutical and Clinical Research, vol. 6, no. 1, pp. 70-76, 2013.

[48] T. Poongodi and R. Hemalatha, "In vitro cytotoxicity, phytochemistry and GC.MS analysis of Pithecellobium dulce leaves," World Journal of Pharmacy and Pharmaceutical Science, vol. 4, pp. 1266-1276, 2015.

[49] C. M. Jardim, G. N. Jham, O. D. Dhingra, and M. M. Freire, "Composition and antifungal activity of the essential oil of the brazilian Chenopodium ambrosioides L.," Journal of Chemical Ecology, vol. 34, no. 9, pp. 1213-1218, 2008.

[50] K. Koba, G. Catherine, C. Raynaud, J. Chaumont, K. Sanda, and N. Laurence, "Chemical composition and cytotoxic activity of Chenopodium ambrosioides L. essential oil from Togo," Bangladesh Journal of Scientific and Industrial Research, vol. 44, pp. 435-440, 2009.

[51] A. G. Al-kaf, R. A. Crouch, A. Denkert et al., "Chemical composition and biological activity of essential oil of Chenopodium ambrosioides from Yemen," American Journal of Essential Oils and Natural Products, vol. 4, pp. 20-22, 2016.

[52] M. S. G. Chekem, P. K. Lunga, J. D. D. Tamokou et al., "Antifungal properties of Chenopodium ambrosioides essential oil against candida species," Pharmaceuticals, vol. 3, no. 9, pp. 2900-2909, 2010.

[53] F. M. Harraz, H. M. Hammoda, M. G. El Ghazouly, M. A. Farag, A. F. El-Aswad, and S. M. Bassam, "Chemical composition, antimicrobial and insecticidal activities of the essential oils of Conyza linifolia and Chenopodium ambrosioides," Natural Product Research (Formerly Natural Product Letters), vol. 29, no. 9, pp. 879-882, 2015.

[54] L. Sagrero-Nieves and J. P. Bartley, "Volatile constituents from the leaves of Chenopodium ambrosioides L." Journal of Essential Oil Research, vol. 7, no. 2, pp. 221-223, 1995.

[55] Z. L. Sousa, F. F. de Oliveira, A. O. da Conceição et al., "Biological activities of extracts from Chenopodium ambrosioides Lineu and Kielmeyera neglecta Saddi," Annals of Clinical Microbiology and Antimicrobials, vol. 11, pp. 20-27, 2012.

[56] R. S. Jesus, M. Piana, R. B. Freitas et al., "In vitro antimicrobial and antimycobacterial activity and HPLC-DAD screening of phenolics from Chenopodium ambrosioides L," Brazilian Journal of Microbiology, 2017.

[57] M. J. Ruffa, G. Ferraro, M. L. Wagner, M. L. Calcagno, R. H. Campos, and L. Cavallaro, "Cytotoxic effect of Argentine medicinal plant extracts on human hepatocellular carcinoma cell line," Journal of Ethnopharmacology, vol. 79, no. 3, pp. 335339, 2002.

[58] L. Barros, E. Pereira, R. C. Calhelha et al., "Bioactivity and chemical characterization in hydrophilic and lipophilic compounds of Chenopodium ambrosioides L.," Journal of Functional Foods, vol. 5, no. 4, pp. 1732-1740, 2013.

[59] D. P. Bezerra, J. D. B. M. Filho, A. P. N. N. Alves et al., "Antitumor activity of the essential oil from the leaves of Croton regelianus and its component ascaridole," Chemistry \& Biodiversity, vol. 6, no. 8, pp. 1224-1231, 2009. 


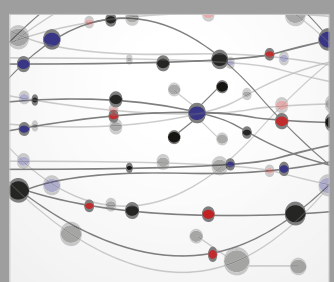

The Scientific World Journal
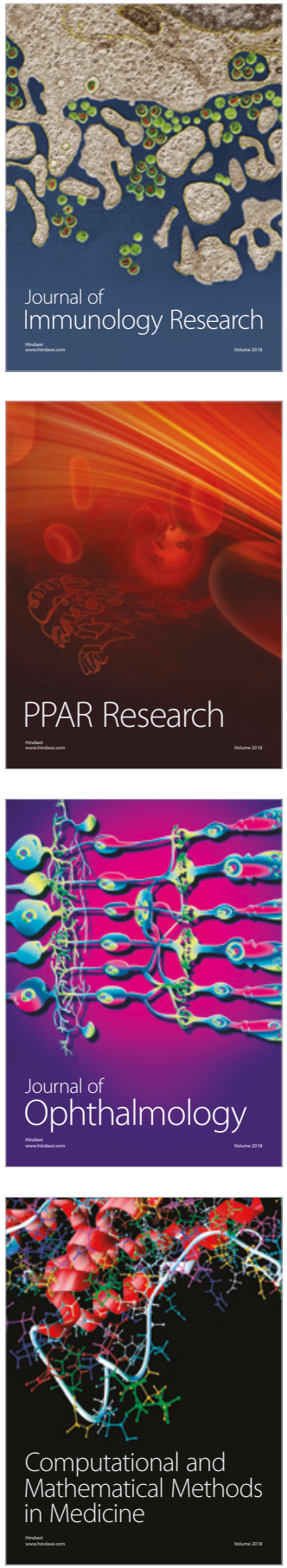

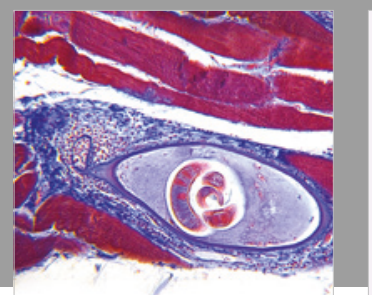

Gastroenterology Research and Practice

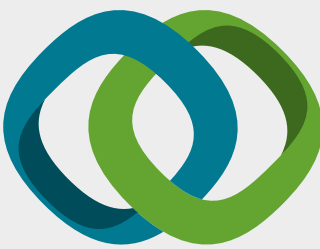

\section{Hindawi}

Submit your manuscripts at

www.hindawi.com
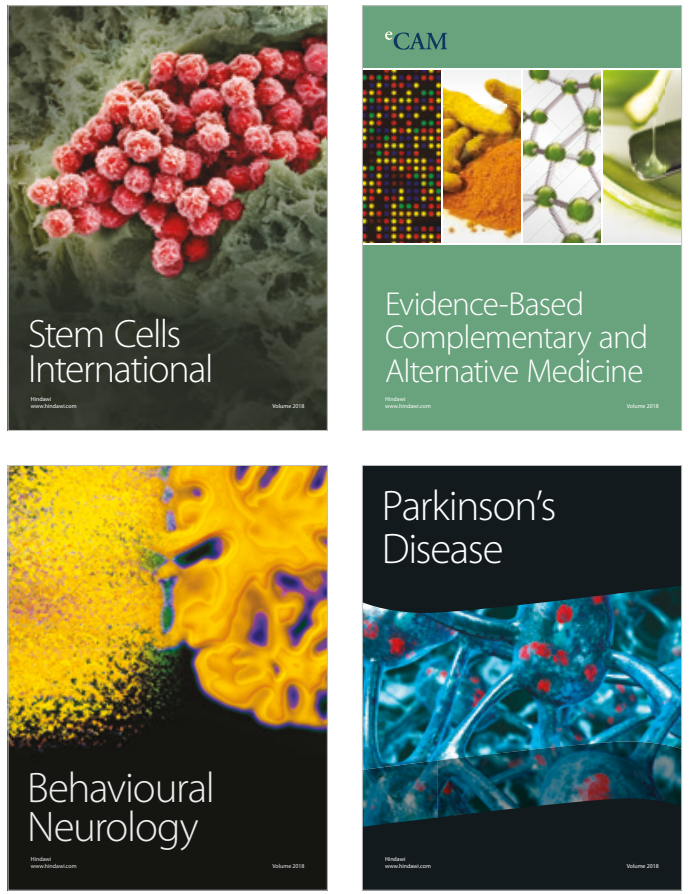

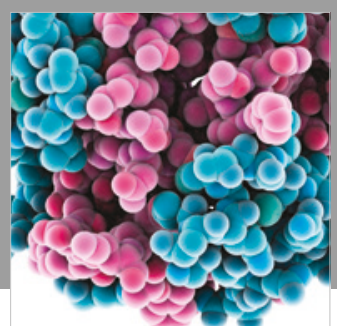

ournal of

Diabetes Research

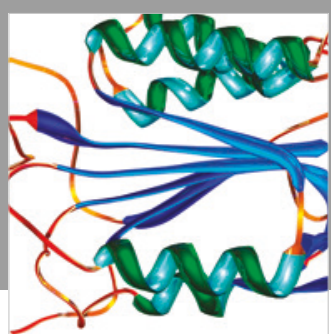

Disease Markers
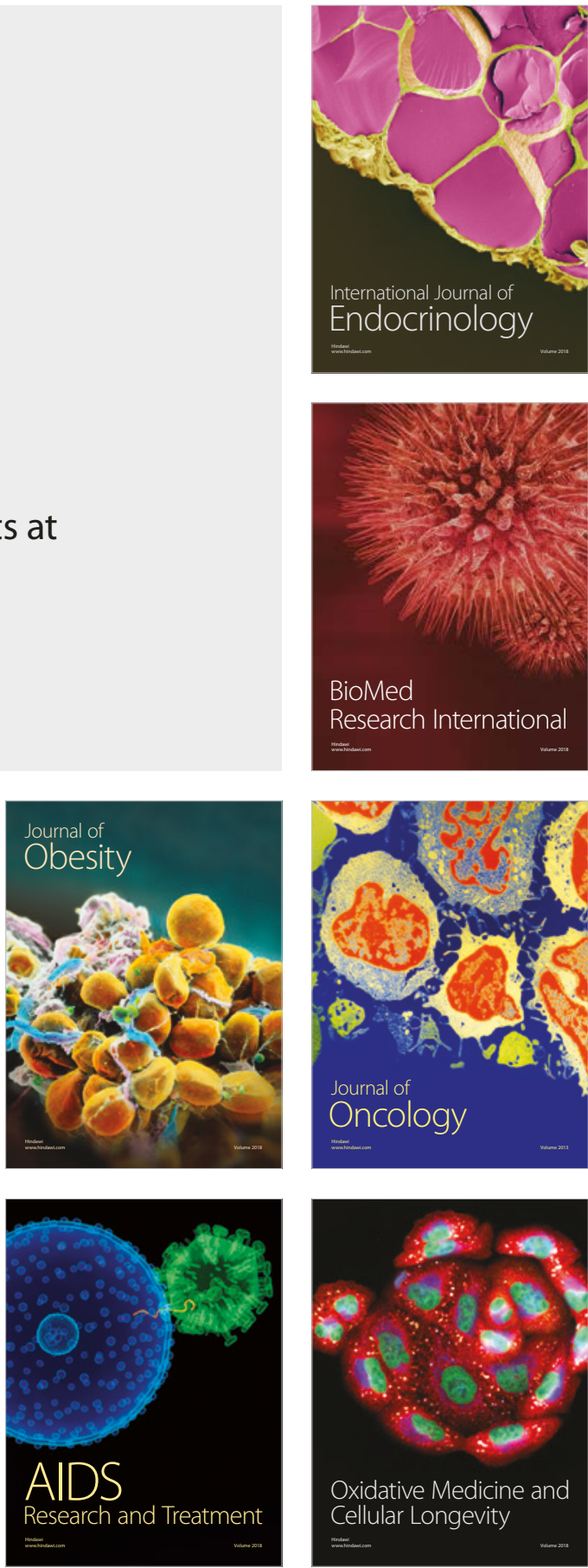